\title{
An Investigation into the Teaching Competency of English Teachers of Tripura Board of Secondary Education
}

\author{
Debabrata Bhattacharjee ${ }^{1} \&$ Remith George Carri ${ }^{2}$ \\ ${ }^{1}$ Post Graduate Teacher, Govt. of Tripura. Email: debabratajoynagar6@gmail.com \\ $\mathcal{E}$ \\ ${ }^{2}$ Assistant Professor, A.M. School of Educational Sciences, Department of Education, \\ Assam University, Silchar
}

\begin{abstract}
The paper intends to identify teaching competency of English teachers at secondary level of Tripura Board of Secondary Education (T.B.S.E.). Descriptive method is applied to collect data and stratified random sampling was applied during the 2016-2017 academic year. A standardized tool was administrated to measure teaching competency of English. The present paper intends to test the significant association of English teaching competency with selected variables. Descriptive statistics and inferential statistics were used to draw inference on the hypothesis. The major recommendations focused that: English teachers of T.B.S.E. should be given individual attention to each of the learners, English teachers of T.B.S.E. should impart teaching properly without discriminating of gender bias, individual attention must be given to poor performing students in English subject, English teachers of T.B.S.E. must not use too much vernacular (mother tongue) languages in the class while teaching a foreign or second language, English teachers of T.B.S.E. should be more punctual, serious while teaching, The teachers of English belonging from T.B.S.E. should be very conscious at preparation, presentation, closing, evaluation and managerial part of the teaching, and should take care of individual attention to each of the learners. The paper grounded the proposition that English teaching competency can be achieved when the three phases of teaching (preactive phase, inter-active phase and post-active phase) will have their proper coordination in terms of context-specific application.
\end{abstract}

Key words: English teaching competency, Secondary level, Stratified sampling, ETCOS.

\section{Conceptual framework}

A competent teacher is identified through his/her transactional phase of teaching and this transactional phase should be inter-linked very closely with the students whom the teacher is imparting teaching (Allen \& Valette, 1997; Quist, 2000). Since to teach is to communicate, English teacher must have required competency for effective communication (Harmer, 2003; Mosha, 2015). The general meaning of the concept of teaching competency is completing a task and being able to effectively fulfill the necessary knowledge, skills and attitudes (King \& Newmann, 2001).A general definition of competency is the level of integration of knowledge, skills, and attitudes (Tigelaar, Dolmans, Wolfhagen, \& Van Der Vleuten, 2004). Hativa, Barak, and Simhi (2001) pointed out that teaching competency is not merely about fitting a particular teaching type or conforming to a set of external criteria; rather, it involves understanding what being a good

(C) AesthetixMS 2020. This Open Access article is published under a Creative Commons Attribution Non-Commercial 4.o International License (http://creativecommons.org/licenses/by-nc/4.o/), which permits non-commercial re-use, distribution, and reproduction in any medium, provided the original work is properly cited. For citation use the DOI. For commercial re-use, please contact editor@rupkatha.com. 
teacher really means and incorporating classroom practices that are appropriate for the wider social context. Oliva and Henson (2001) identified twenty three essential teaching competencies to all teachers and grouped around five major categories: knowledge of basics, communication skills, technical skills, interpersonal skills and administrative skills (Appleton- Knapp \& Krentler, 2006; Clayson, 2005; Desai, Damewood, \& Jones, 2001; Faranda \& Clarke, 2004; Kelley, Conant \& Smart, 1991).Teachers' knowledge and understanding of psychology of the learners and application of teaching in that way ( Biddle,1964); stimulation of interest of the learners, proper knowledge of subject matter, helping attitude to the learners ( Feldman,1976); teaching experience has positive relationship with teaching competency ( Sharma,1970); proper knowledge about the learner and behavioural modification of the learners while imparting teaching ( Borich,1977) ; knowledge of curricula, teaching methods, knowledge of proper skills of teaching ( McDonalds,1978); good communication skills from the part of the teacher and helping attitude can be the characteristics of a competent teacher ( Feldman,1988); proper classroom management and knowledge of learning situation ( Chen \& Lin, 2009) etc. are some of the important aspects which can ensure teaching competency. In the similar ways, Bargava (2011) argues that skill of presentation of subject matter, motivating the learners, warm and cordial behavour are some of the important aspects of a competent teacher. Prakashan (1986) identified the effect of organizational climate on teacher effectiveness and the study revealed that the teachers who are working in schools run by the local bodies display better teaching competency than other schools. The studies (Sharma, 1970; Sridhar, 1991; Mohanty, 1994) inferred that teaching experience and locale of the school and educational qualification of the teachers are very important for teaching competency.

Teaching competency is one or more abilities of a teacher to produce agreed upon educational effects. The term teaching is a complex skill and can be defined as a set of observable teacher behaviours that intend to facilitate learning in the pupils. Teaching is comprised of teaching skill, which have specific instructional objective to be achieved. Teaching competency means the right way of conveying set of knowledge, skills and application to the students by understanding and applying the child psychology also. Debnath (1971) reveals that age, experience, academic achievement and professional training are significant determinants of teaching competency. In a study of Sharma (1971), the combination of five predictors i.e., teaching aptitude, academic grades, socio-economic status, teaching experience, and age, in that order, appeared to be sound predictors of teaching competency. Sharma (1971) reveals that academic grade as main predictor of teaching competency. He also found the positive relationship between teaching experience and teacher effectiveness. Feldman (1976) analyzed seventy two studies on characteristics reported by college students as associated with ideal teachers and as important for competent teaching. Friendliness, helpfulness, and openness to others' opinions were traits that students said they preferred in teachers especially when they freely described their ideal or best teacher. Ganaie and Mudasir (2014) inferred that male teachers of Secondary level showed better teaching competency as compared to the female teachers of Secondary level whereas, Singh (2008) opined that gender had no significant impact on teaching competency. Anbuthasan and Balakrishan (2013) showed that there was significant difference between rural area teachers and urban area teacher and the teachers of urban area displayed better teaching competency and the study too indicated that gender, age and local were some influential factors of teaching competency. Besides, Martin and Smith (1990) inferred that teachers' age was grouped into three levels - young age, middle age and old age; it too revealed that middle aged teachers were perceived by learners to be more effective in classroom organization, motivation, communication and competence. 
Since, age, gender, locale etc. are some of the prominent influential indicators to influence teaching competency, the researchers intend to identify the whether there is any association among teaching competency in English with age, gender and locale in the purview of secondary level in Tripura.

\section{The study and its delimitations}

English subject in spite of its worldly importance, considers as one of the most difficult foreign language in Tripura. In state board of Tripura which is Tripura Board of Secondary Education (T.B.S.E) is the most popular board in terms of students' enrolment. Age, gender and locale of English teachers do play a very crucial role to identify a competent English teacher.

The present paper is an attempt to find-out the association of the predictor variables (age, gender, locale) on outcome (English teaching competency) at secondary level of T.B.S.E. board.

\subsection{Conceptual model}

\section{Diagram: 1.1}

Predictor

\section{Outcome}

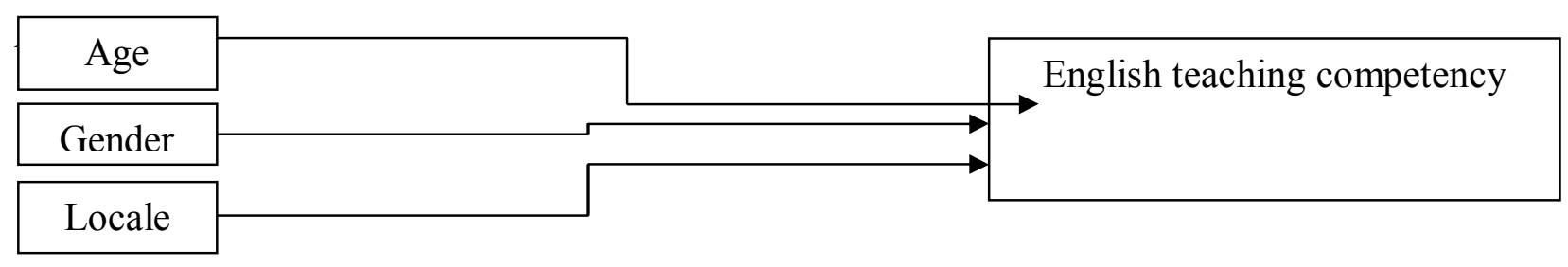

\subsection{Hypotheses}

There is no significant association of English teaching competency of T.B.S.E. teachers with respect to locale of the school and to their age and gender.

Since all the three variables cannot be tested together, three sub-hypotheses were proposed and are tested one by one. The sub-hypotheses were:

i-a)There is no significant association of English teaching competency of T.B.S.E. teachers with respect to the locale of the school.

i-b) There is no significant association of English teaching competency of T.B.S.E. teachers with respect to their age.

i-c) There is no significant association of English teaching competency of T.B.S.E. teachers with respect to their gender.

\subsection{The study and its design}

The present study falls under descriptive research design. English teachers who are teaching in $10^{\text {th }}$ standard belonging to T.B.S.E. board of Tripura have constituted the population of the present study. Twenty English teachers have chosen as the sample of the study through stratified random sampling technique. Initially the researcher selected 10 schools from T.B.S.E. For this the researcher first made a list of schools under T.B.S.E, the urban and the rural schools were separated out. From this second stratum, 5 urban and 5 rural schools were selected randomly 
from each board. This resulted in selection of 10 schools out of which 5 schools are T.B.S.E. rural schools, 5 schools are T.B.S.E. urban school.

\subsection{Tool}

'English Teaching Competency Observation Scale' (ETCOS) was developed and standardized with the five major areas named:
A. Planning
B. Presentation
C. Closing
D. Evaluation
E. Managerial

\subsection{Standardization of ETCOS}

\subsubsection{Validity:}

Content Validity Ratio (C.V.R.) and Content Validity Index (C.V.I.) which was put forward by Lawshe (1975) were measured. Minimum C.V.R required to retain an item when scored by 15 experts is $\mathbf{0 . 4 9}$ and 46 items of the tool got a score more than .49. Content Validity Index (C.V.I.) was o.69. Hence; items are found to be essential for the tool. Thus validity of 'English Teaching Competency Observation Scale' (ETCOS) was secured.

\subsubsection{Reliability}

As it was under the direct classroom observation hence reliability was not measured and no interrater reliability was calculated.

\subsection{Scoring pattern of the tool}

\section{To study English teaching competency:}

English Teaching Competency Observation Scale (ETCOS) is a Five-point Likert Scale which has in total 46 items; the scale has five major sections (A:Planning (Pre-instructional,

Presentation ( Instructional), C:Closing, D: Evaluation, E :Managerial) and these five major sections have their own segmentations. The highest score of ETCOS is $230\left(46^{*} 5\right)$ and the lowest score is $46\left(1^{*} 46\right)$. Through the ratings against the 46 items by the researcher, 20 English teachers of T.B.S.E. from classroom teaching of English subject of $10^{\text {th }}$ standard during the 2017-2018 Academic Year were observed. As per the observation of English teaching subject, rating was given to every individual teacher of English and the three groups were identified (based on received scoring through ETCOS) such as Low Competency Group (120-160), Average Competency Group (161-200) and High Competency Group (201 and above). Thus, these three groups helped to distinguish English teachers as per sum total rating scores through ETCOS by the researcher. Thus, in this entire process, the researcher observed 20 classrooms with ETCOS to measure English teaching competency. 20 English teachers from rural and urban areas belonging to T.B.S.E. board of Tripura. A 5 point Liker scale for ETCOS was used and helped the researcher to 
get a complete and specified data to get the actual picture of English teaching competency in $10^{\text {th }}$ standard level from the observed classroom teaching.

\section{Data analysis}

For testing association of English teaching competency with selected variables, the investigator classified English teaching competency in to the three levels that is 'Low', 'Average', and 'High' competency. The maximum score for competency was 230 and the score secured by the teachers were grouped as 120-160 as low competency, 161-200 as average competency, and 201- above as high competency. Based on the level of competency investigator find out the association among 'Gender', 'Age' and the 'Locale' of competency using 'Chi-squire Test'. The researcher decided to do the Non-parametric test here since the sample size is not enough for generalization.

The hypothesis was proposed: There is no significant association of English teaching competency of T.B.S.E. teachers with respect to the locale of the school and to their age and gender and to test the hypothesis Chi-square method is applied which is presented through the table :

To find-out the association between 'English teaching competency' and 'Locale', Chi-square method was applied and is presented through the table below:

\section{Table 1.1}

Data and result of test of significance in the association between 'Locale' and 'English teaching competency' of T.B.S.E. Teachers.

\begin{tabular}{|c|c|c|c|c|}
\hline \multirow[t]{2}{*}{ Competency } & \multirow[t]{2}{*}{ Reponses } & \multicolumn{2}{|c|}{ Locality } & \multirow[t]{2}{*}{ Total } \\
\hline & & Rural & Urban & \\
\hline \multirow[t]{2}{*}{ Low Competency } & Count & 3 & 3 & 6 \\
\hline & $\%$ & $30.0 \%$ & $30.0 \%$ & $30.0 \%$ \\
\hline \multirow{2}{*}{$\begin{array}{c}\text { Average } \\
\text { Competency }\end{array}$} & Count & 6 & 7 & 13 \\
\hline & $\%$ & $60.0 \%$ & $70.0 \%$ & $65.0 \%$ \\
\hline \multirow[t]{4}{*}{ High Competency } & Count & 1 & o & 1 \\
\hline & $\%$ & $10.0 \%$ & $0.0 \%$ & $5.0 \%$ \\
\hline & Count & 10 & 10 & 20 \\
\hline & $\%$ & $100.0 \%$ & $100.0 \%$ & $100.0 \%$ \\
\hline
\end{tabular}

$\mathrm{X}^{2}=1.46, \mathrm{p}>0.05$

From the above table it is clear that the Chi-squire value 1.46 is not significant at 0.05 ( $\mathrm{p}>0.05$ ) level of significance. That means there exist no significant association between 'Locale' and 'English teaching competency'. So, the hypothesis stated that: There is no significant association of English teaching competency of T.B.S.E. teachers with respect to the locale 
of the school is not rejected. Hence it can be concluded that 'English teaching competency' of T.B.S.E. teachers have no difference irrespective their 'Locale' and is not associated with the locale of the teachers.

According to Liakipoulou, Whichade and Whiwatnakul, (2012) pedagogical knowledge, content mastery, selection and application of T.L.M. (teaching-learning material) etc. are very vital for English teaching competency and are needed for an effective English teacher; the English teacher should apply these indicators irrespective of rural or urban area posting.

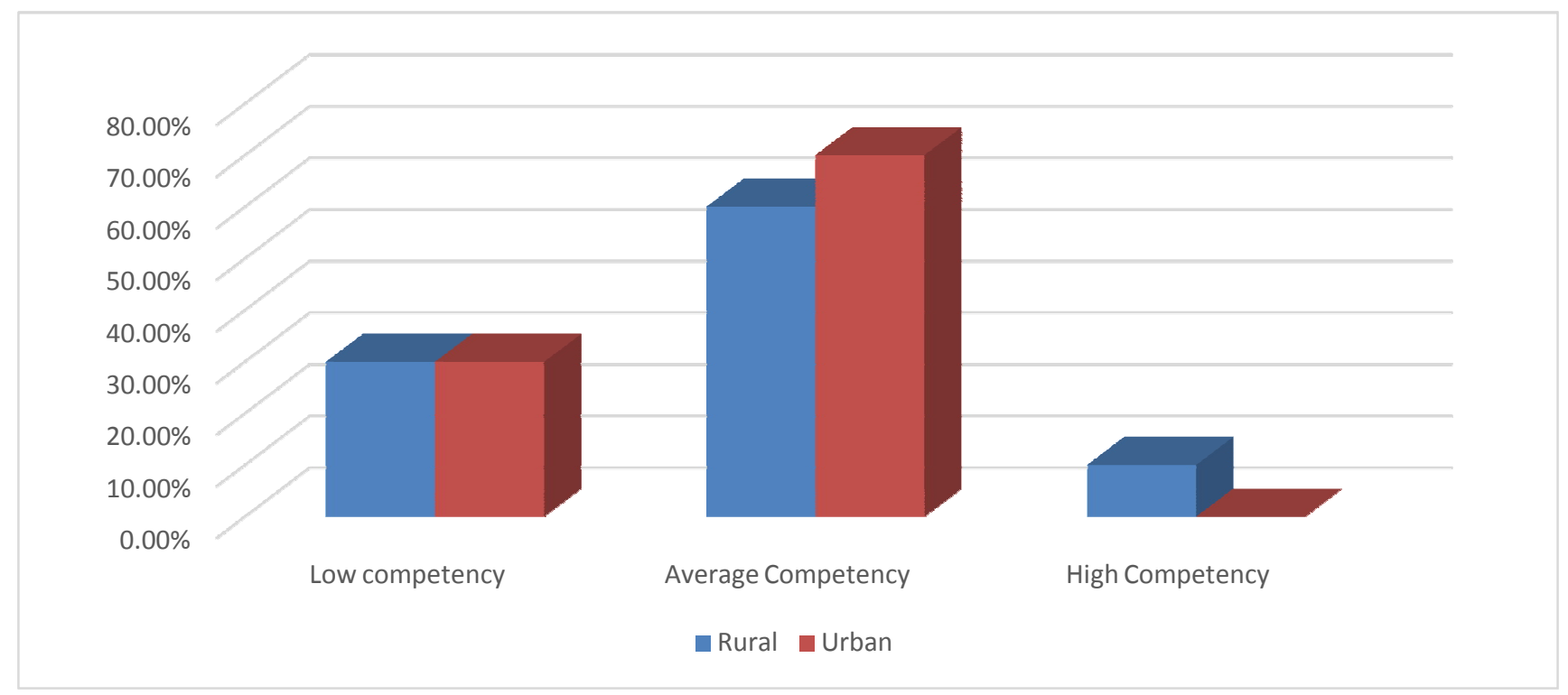

Figure. 1.1

Percentage of Rural and Urban teachers in their level of English teaching competency in T.B.S.E.

Analysis: The figure indicates that the teachers of T.B.S.E. who belong to 'Low Competency' group (120-160) in 'English teaching competency' is same in both the Rural and the Urban area as both the groups belong to the percentage below 30\%. The 'Average Competency' group (160-200) in 'English teaching competency' of the Rural area teachers is less (below 6o\%) whereas the Urban area teachers have better (above 6o\%) 'English teaching competency'. The 'High Competency' group (201 and above) is very rare; although only below $10 \%$ of the Rural teachers do belong to this category whereas no teachers of the Urban area belong to this group.

To find-out the association between 'English teaching competency' and 'Age', Chi-square method was applied which is presented through the table:

\section{Table 1.2}

Association between 'Age' and 'English teaching competency' of T.B.S.E. Teachers.

\begin{tabular}{|c|c|c|c|c|}
\hline \multirow{2}{*}{ Competency } & \multirow{2}{*}{} & \multicolumn{2}{|c|}{ Age } & \multirow{2}{*}{ Total } \\
\cline { 3 - 4 } & & Below 50 & Above 50 & \\
\hline Low competency & Count & 6 & 0 & 6 \\
\hline
\end{tabular}



An Investigation into the Teaching Competency of English Teachers of Tripura Board of Secondary Education

\begin{tabular}{|c|c|c|c|c|}
\hline & $\%$ & $42.9 \%$ & $0.0 \%$ & $30.0 \%$ \\
\hline \multirow{2}{*}{ Average Competency } & Count & 7 & 6 & 13 \\
\cline { 2 - 5 } & $\%$ & $50.0 \%$ & $100.0 \%$ & $65.0 \%$ \\
\hline \multirow{2}{*}{ High Competency } & Count & 1 & 0 & 1 \\
\cline { 2 - 5 } & $\%$ & $7.1 \%$ & $0.0 \%$ & $5.0 \%$ \\
\hline & Count & 14 & 6 & 20 \\
\cline { 2 - 5 } & $\%$ & $100.0 \%$ & $100.0 \%$ & $100.0 \%$ \\
\hline
\end{tabular}

$\mathrm{X}^{2}=6.49, \mathrm{p}<0.05$

From the above table, it can be argued that the Chi-squire value 6.49 is significant at $0.05(\mathrm{p}<0.05)$ level of significance. That means there exists a significant association between age and English teaching competency; hence the hypothesis stated that: There is no significant association between English teaching competency of T.B.S.E. teachers with respect to age is not accepted. So it can be concluded that 'Age' of teachers is an associative factor on 'English teaching competency' of T.B.S.E. teachers.

Trivedi (2004) identified that the teachers who are of above 50 years are found less competent in terms of execution of teaching in instructional phase than of the teachers below 40 years. The study of Mcdonald (2007) revealed that the impact of competency on English teaching based on some variables such as age, span of teaching experience. The findings of the study revealed that age of the English teachers can be attributed for a successful and competent English teacher. The findings revealed that the teachers whose age group belongs to 25 to 40 years can display better English teaching competency than of the other age group English teachers such as $41-45$ agegroup teachers and above.

In state board (T.B.S.E.), most of the English teachers are above 40 years of age. The age-group plays an important role in order to obtain teaching competency. As most of the T.B.S.E. schools, there are English teachers who are not young rather old one; so at their age level lethargy dominates them and they take classes with very casual manner.

The Chi-square value 6.49 is greater than the table value 1.96 is not significant at 0.05 level of significance. Hence, the sub-hypothesis stated that: There is no significant association of English teaching competency of T.B.S.E. teachers with respect to their age of the school is not accepted. 


\section{Figure. 1.2}

Percentage of the level of 'Age' of teachers in their level of 'English teaching competency' in the T.B.S.E.

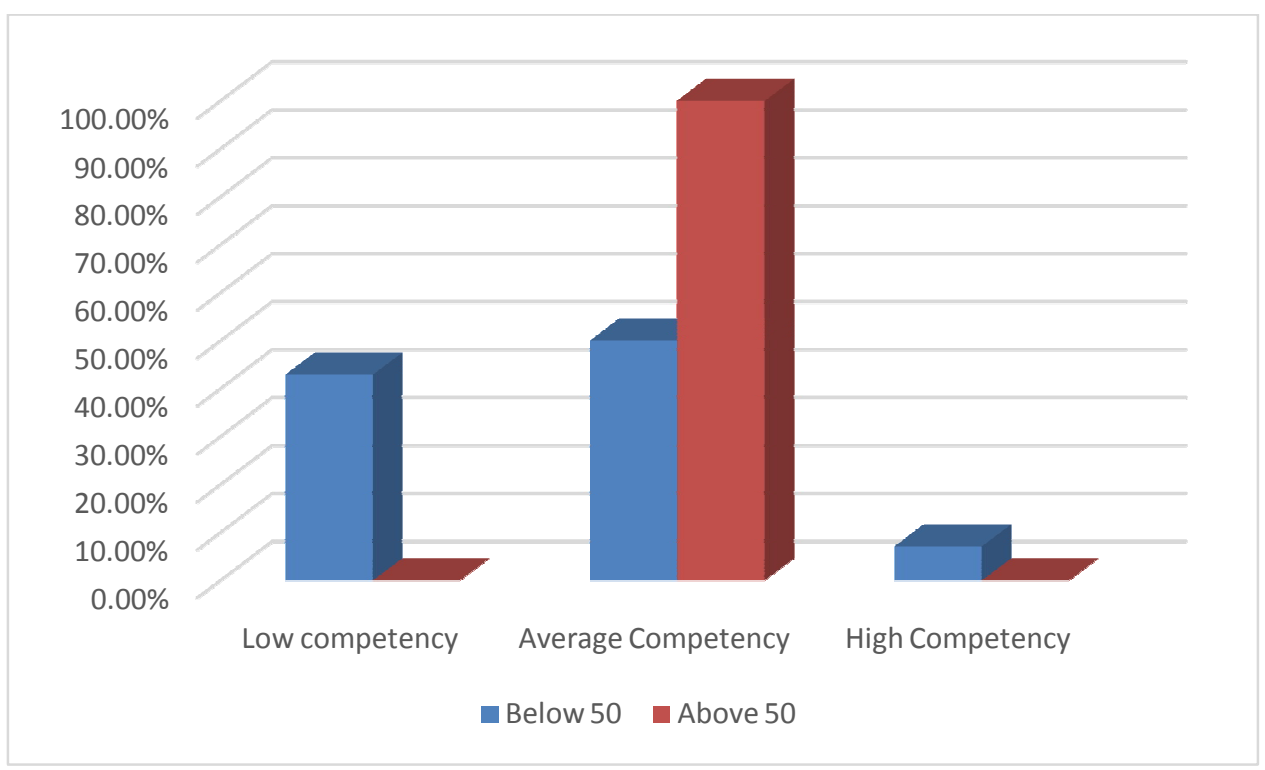

Analysis: The figure indicates that there are two groups based on age: one group is 'Below 50 Years' of age and another is 'Above 50 Years' of age. In 'Low Competency' group, the teachers who are 'Below 50 Years' of age are almost 40\% but no teachers of 'Above 50 Years' of age-group are found who do belong to 'Low Competency' group.

In case of 'Average Competency' group, the teachers who do belong to the age-group of 'Below 50 Years' of age, just below 50\% whereas, 'Above 50 Years' of age-group teachers are above 90\%.

But in case of 'High Competency' group, the teachers who belong to 'Below 50 Years' of age do fall with very less percentage (only below 10\%) whereas; there are no teachers of 'Above 50 Years' of age-group are found.

To know the association between 'English teaching competency' and 'Gender', Chi-square method was applied which is presented through the table:

\section{Table 1.3}

Association between level of 'English teaching competency' and 'Gender' of the T.B.S.E. Teachers

\begin{tabular}{|c|c|c|c|c|}
\hline \multirow{2}{*}{ Competency } & \multirow{2}{*}{} & \multicolumn{2}{|c|}{ Gender } & \multirow{2}{*}{ Total } \\
\cline { 3 - 4 } & & Male & Female & \\
\hline \multirow{2}{*}{ Low competency } & Count & 2 & 4 & 6 \\
\cline { 2 - 5 } & $\%$ & $25.0 \%$ & $33.3 \%$ & $30.0 \%$ \\
\hline
\end{tabular}



An Investigation into the Teaching Competency of English Teachers of Tripura Board of Secondary Education

\begin{tabular}{|c|c|c|c|c|}
\hline \multirow{2}{*}{ Average Competency } & Count & 5 & 8 & 13 \\
\cline { 2 - 5 } & $\%$ & $62.5 \%$ & $66.7 \%$ & $65.0 \%$ \\
\hline \multirow{2}{*}{ High Competency } & Count & 1 & 0 & 1 \\
\cline { 2 - 5 } & $\%$ & $12.5 \%$ & $0.0 \%$ & $5.0 \%$ \\
\hline \multirow{2}{*}{ Total } & Count & 8 & 12 & 20 \\
\cline { 2 - 5 } & $\%$ & $100.0 \%$ & $100.0 \%$ & $100.0 \%$ \\
\hline
\end{tabular}

$\mathrm{X}^{2}=1.95, \mathrm{p}>0.05$

From the above table, it is shown shows that the Chi-squire value 1.95 is not significant at 0.05 level of significance which means that there exists no significant association between 'Gender' and 'English teaching competency' of T.B.S.E. teachers; hence the hypothesis stated that: There is no significant association between English teaching competency of T.B.S.E teachers with respect to their gender is not rejected. So it can be concluded that 'English teaching competency' is not associated with the 'Gender' of the teachers belonging to T.B.S.E.

Figure. 1.3

Percentage of teachers having 'English teaching competency' of between 'Male and Female teachers' in T.B.S.E.

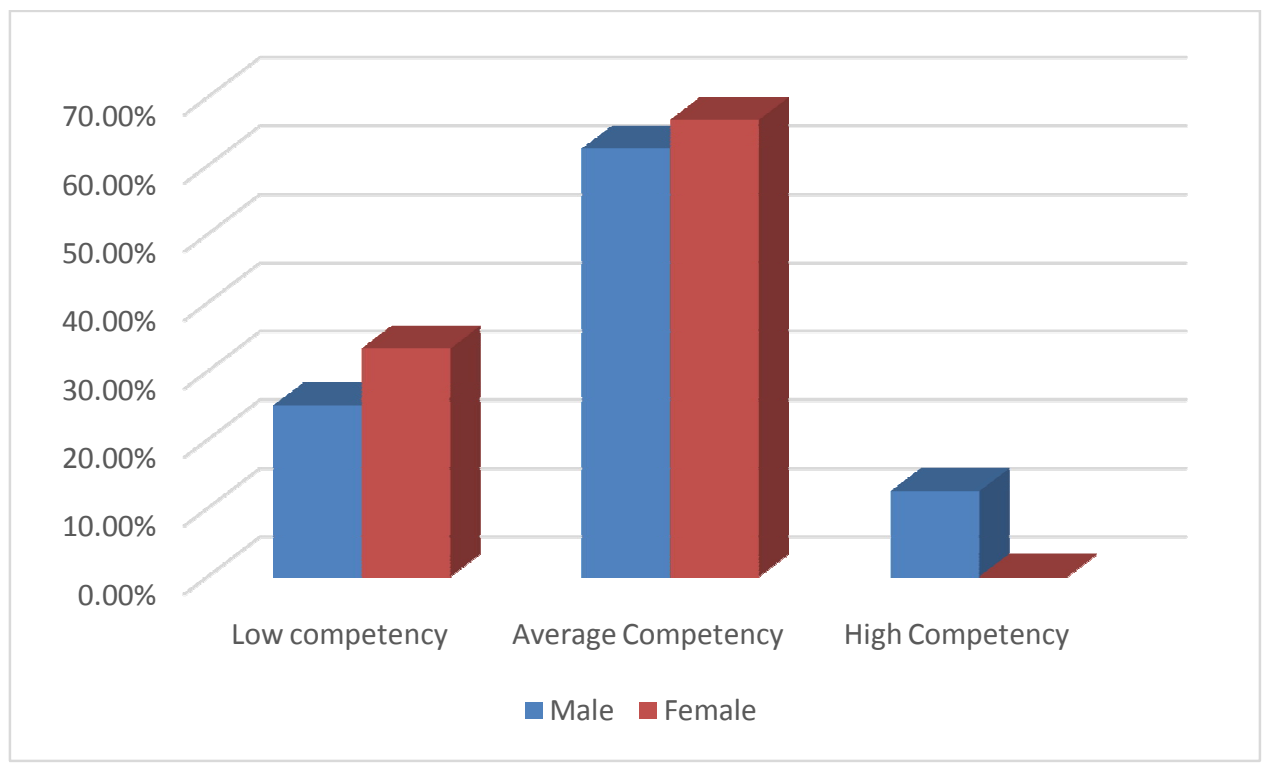

Analysis: The figure indicates that there are three groups with regard to 'Low Competency', 'Average Competency' and 'High Competency' of Male and Female teachers. The percentage of Male teachers with regard to 'Low Competency' is below 30\% and Female teachers are occupying above $30 \%$ in this group of 'Low Competency'.

In case of 'Average Competency' group, the Male teachers do fall just below $60 \%$ whereas Female teachers do fall just above $60 \%$. 
The Male teachers dominate (with below 10\%) in case of 'High Competency' group as there is no such candidate is found from the female teachers in 'High Competency' group.

\section{Findings}

'English teaching competency' of T.B.S.E. teachers has no difference irrespective their 'Locale' and is not associated with the locale of the teachers; 'Age' of teachers is an associative factor on 'English teaching competency' of T.B.S.E. teachers. Besides, 'English teaching competency' is not associated with the 'Gender' of the teachers belonging to T.B.S.E.

\section{Recommendations}

$>$ English teachers of T.B.S.E. should be given individual attention to each of the learners.

$>$ English teachers of T.B.S.E. should impart teaching properly without discriminating of gender bias.

$>$ Individual attention must be given to poor performing students in English subject.

$>$ English teachers belonging to T.B.S.E. must not use too much vernacular (mother tongue) languages in the class while teaching a foreign or second language.

$>$ English teachers of T.B.S.E. should be more punctual, serious while teaching. They should be very conscious at preparation, presentation, closing, evaluation and managerial part of the teaching.

$>$ English teachers belonging to T.B.S.E should give individual attention to each of the learners.

\section{Conclusion}

Teaching competency can be achieved when the three phases of teaching (pre-active phase, interactive phase and post-active phase) have their proper coordination. This coordination has its context-specific relevance in teaching as these three phases of teaching have their sub-elements such as preparation, announcement, black-board work, questioning, voice modulation, individual attention, eye-contact, impartial behaviour, sitting arrangement, recapitulation of lesson etc. These sub-elements are some of the process indicators which help to identify competency in teaching in specific teaching-learning context. Ecverarria (1995), Kaufffman, Sheppard, Burkart, Peyton and Short (1995), Genesee (1999), Vogt (2000), Echevarria and Graves (2003) have identified certain teaching techniques such as slower speech, use of visuals, scaffold instruction, relating learners to learners experiences, learner to learner interaction, adopting learning materials to students' level, use of enriched learning materials to support and enhance students' learning indicators which contribute better teaching performance. Hence, English teachers of T.B.S.E. should strictly keep these aspects in mind irrespective of their age, gender and locale of their posting in order to bring and sustain better competency while transacting teaching English subject at secondary level. 


\section{References}

Allen, E., \& Valette, R. (1997). Classroom techniques: Foreign languages and English as a second language. San Diego: Harcourt Brace Jovanovich.

Anbuthasan, A., \& Balakrishnan, V. (2013). Teaching competency of teachers in relation to gender, age and locality. International Journal of Teacher Educational Research (IJTER), 2(1), 31-35.

Appleton-Knapp, S. L., \& Krentler, K.A. (2006). Measuring student expectations and their effects on satisfaction: The importance of managing student expectation. Journal of Marketing Education, 28(3), 254-264

Best, J. W., \& Kahn. J. V. (2012). Research in Education. New Delhi: Prentice-Hall of India Private Limited.

Bargava, A.(2011). Perception of student teachers about teaching competencies. American International Journal of Contemporary Research, 1 (1), 77-81.

Biddle, B., \& Ellena, W. (1964). Contemporary research on teacher effectiveness. New York: Holt Rinehart and Winsten, 1-10.

Borich, G.D. (1977). The appraisal of teaching: Concepts and process. Menlo Park, CA: Addison-Wesley.

Clayson, D. E. (2005). Within-class variability in student-teacher evaluations: Examples and problems. Decision Sciences Journal of Innovative Education, 3(1), 109-124.

Chen, Y. J., \& Lin, S.C. (2009). Exploring characteristics for effective EFL teachers from the perceptions of junior high school students in Tainan. STUT Journal of Humanities and Social Sciences, 2, 219-249

Debnath, H.W. (1971). Teaching efficiency: Its measurement and some determinants, Ph.D. Edu., ViswaBharathi University. Sciences, 2, 219-249.

Desai, S., Damewood, E., \& Jones, R. (2001). Be a good teacher and be seen as a good teacher. Journal of Marketing Education, 23(2), 136-144.

Echevarria, J. (1995). Sheltered instruction for students with learning disabilities who have limited English proficiency. Intervention in School and Clinic, 30(5), 302-305. Retrieved, $29^{\text {th }}$ June, 2014, from http://dx.doi.org/10.1177/105345129503000509

Echevarria, J., \& Graves, A. (2003). Sheltered content instruction: Teaching English language learners with diverse abilities. Boston: Allyn \& Bacon.

Faranda, W.T., \& Clarke I. (2004). Student observations of outstanding teaching: Implications for marketing educators. Journal of Marketing Education, 26(3), 271-281.

Feldman, K. A. (1976). The superior college teacher from the students' view. Research in Higher Education, 5(3), $243-288$.

Feldman, K. A. (1988). Effective college teaching from the students' and faculty's view: Matched or mismatched priorities? Research in Higher Education, 28(4), 291-344.

Ganaie, M.Y., \& Hafiz, M. (2014).A comparative study of teaching competency of secondary school teachers in district Srinagar. Report and Opinion, 6(6), 49-54.

Genesee, F. (Ed.). (1999). Program alternatives for linguistically and culturally diverse students (Educational Practice Report No. 1). Santa Cruz, CA: Center for Research on Education, Diversity \& Excellence.

Harmer, J. (2003). The practice of English language teaching. Malaysia: Longman.

Hativa, N., Barak, R., \& Simhi, E. (2001). Exemplary university teachers: Knowledge and beliefs regarding effective teaching dimensions and strategies. The Journal of Higher Education, 72(6), 699-729.

Kauffman, D., Sheppard, K., Burkart, G., Peyton, J., \& Short, D. (1995). Content-ESL across the USA (Vol-II, Tech, Rep.). Washington DC: National Clearinghouse for Bilingual Education. 
Kelley, C.A., Conant, J.S., \& Smart, D.T. (1991). Master teaching revisited: Pursuing excellence from the students' perspective. Journal of Marketing Education, 13, 1-10.

King, M. B., \& Newmann, F. M. (2001). Building school capacity through professional development: Conceptual and empirical considerations. International journal of educational management, 15(2), 8694.

Liakopoulou, M. (2012). The professional competence of teachers: Which qualities, attitudes, skills and knowledge contribute to a teacher's effectiveness? International Journal of Humanities and Social Science,1 (21), 66-78.

Martin, K.J., \& Smith, L.R. (1990). Effects of teachers age and gender on student perception. Educational Resources Information Centre ( ERIC), U.S.A.

McDonald, F. (1978). Evaluating pre-service teacher's competence. Journal of Teacher Education, 2, 29-33.

Mcdonald, R. (2007). Predictive variables on English teaching competency. Delhi: Joypee Books Concern Publishing House.

Mohanty, A.K. (1994). Bilingualism in a multilingual society: Psycho-social and pedagogical implication. Central Institute of Indian Languages, Mysore.

Mosha, M.A. (2015). The role of teachers' resource centres in teachers' professional development and enhancing primary education in Zanzibar. Journal of Education and Practice,6(8),44-46.

Oliva, P. F., \& Henson, K. T. (2001). What are the essential generic teaching competencies? Education, $19(2), 117-121$.

Pachaiyappan, R. (2014).Evaluating the teacher effectiveness of secondary and higher Secondary school teachers, IOSR Journal of Research \& Method in Education (IOSR JRME), 4(1),52-56.

Prakashan, D. (1986). A study of teacher effectiveness as a function of school organizational climate and teaching complementary. In M.B. Buch (Eds.), Fourth Survey of Research in Education (1991), Vol.II., New Delhi: NCERT, 1036.

Quist, D. (2000). Primary teaching methods. London: Macmillan.

Sharma, M. (1970). A study of values and teachers. M.Ed. Dissertation, Univ. of Rajasthan.

Sharma, P. (1971). Motivational factors in teaching. Agra: Trivedi Publishing House.

Singh, S. (2008). A study of teaching competency of secondary school teachers in relation to gender and teaching experience. Indian Journal of Educational Research, 27(2), 63-68.

Singh, S.K. (2009). Methodology of research in education. New Delhi: Sterling Publishers Private Limited.

Sridhar, M. (1991).Transactional insight into teaching quality. Patna: Saxeena House of Publishing Private Limited.

Tigelaar, D. E. H., Dolmans, D. H. J. M., Wolfhagen, I. H. A. P., \& Van, D. (2004). The development and validation of a framework for teaching competencies in higher education. Higher Education, 48, 253268.

Trivedi, S. (2004). Transaction of teaching in diversified settings. Nirupa Publishing House: Agra.

Vogt, M.E. (2000). Content learning for students needing modifications : An issue of access. In McLaughliln, M., \& Vogt, M.E. (Eds.), Creativity and innovation in content area teaching, 329-351, Norwood, MA.:

Christopher-Gordon. 